\title{
Ut cantor declamator? \\ O podobieństwach i różnicach między recytatorską a wokalno-muzyczną interpretacją tekstu
}

DOI: http://dx.doi.org/10.12775/LC.2016.003

\begin{abstract}
Streszczenie. Między interpretacją recytatorską a wokalno-muzyczną tekstu występuje wiele podobieństw wynikłych ze wspólnego głosowego tworzywa. Występują tu także różnice - związane m.in. z sytuacją wykonawczą: recytator kieruje się dyrektywą tekstu, śpiewak czy piosenkarz otrzymuje ją od kompozytora, który tekst muzycznie opracował. Kompozytor może stać blisko recytatora, gdy daje pierwszeństwo tekstowi, nierzadko szukając inspiracji w substracie intonacyjnym, może się od niego oddalać, gdy uniezależnia stronę muzyczną od tekstu. Przykłady tego znajdziemy w pieśni, operze i poezji śpiewanej.
\end{abstract}

Słowa kluczowe: interpretacja recytatorska tekstu; interpretacja wokalno-muzyczna tekstu; pieśń; opera; poezja śpiewana

\section{Summary}

\section{Ut cantor declamator?}

\section{Declamatory and vocal-musical interpretation of text: similarities and differences}

There are many similarities, resulting from a common voice material, between declamatory and vocal-musical interpretation of text. But there are also differences related to, among others, the performing situation: reciter is guided by the directive of the text, singer or singers receive it from

\footnotetext{
* Doktor habilitowany, obecnie na emeryturze. Pracował na Uniwersytecie Mikołaja Kopernika w Toruniu na stanowisku profesora. Prowadził zajęcia m.in. z dydaktyki literatury i języka polskiego oraz z kultury żywego słowa. E-mail: vladsav@wp.pl
} 
a composer who developed the musical text. A composer can stay close to a narrator giving priority to the text, often seeking inspiration in the intonation substrate. He also can, however, move away from a narrator when he frees the musical side from the text. Examples of this can be found in songs, opera, and sung poetry.

Keywords: declamatory interpretation of text; vocal-musical interpretation of text; song; opera; sung poetry

ecytator, który wykonuje swoją czynność recytowania, występuje w zasadzie w dwojakiej roli: kolportera czy prezentera tekstu z jednej strony i jego interpretatora $\mathrm{z}$ drugiej. Czyni to w jednym akcie wykonawczym, ponieważ nie istnieje „czysta” prezentacja, jak nie istnieje jakakolwiek „czysta” lokucja, a jedynie względy heurystyczne i opisowe każą te dwa zjawiska od siebie oddzielić. Nie trzeba też przekonywać, że byłoby ontologiczną niedorzecznością zakładanie istnienia interpretacji bez prezentacji. Jedna i druga funkcja będzie przedmiotem naszej uwagi w toku dalszych rozważań, spośród nich zwłaszcza ta pierwsza, interpretacyjna.

Interpretacja głosowa tekstu ma charakter linearny. Głoska po głosce, słowo po słowie, zdanie po zdaniu, wers po wersie dokonuje recytator swojej explication de texte, zaś charakter tworzywa sprawia, że ta explication układa się w nieprzerwane continuum i może stać się precyzyjną odpowiedzią na zapotrzebowanie interpretacyjne tekstu, oczywiście na miarę możliwości, jakimi tu dysponuje głos. Bowiem głos jest tworzywem recytacji. Struktura fizyczna głosu oraz prozodyczne, w najszerszym znaczeniu słowa, środki wyrazowe czynią recytację narzędziem interpretacyjnym szczególnie atrakcyjnym. Recytator nie może zastąpić krytyka literackiego czy badacza z ich metatekstowymi interpretacjami, ale może dokonać dostępnej mu interpretacji holistycznej, nieskrępowanej schematyzmem, uproszczeniami czy ideacjami poznania dyskursywnego, interpretacji, w której znajduje swoje odzwierciedlenie Bergsonowskie poznanie intuicyjne, dokonujące się w odniesieniu do całego utworu w jego makro- i mikrowymiarach. Do tego trzeba dodać, że chodzi tu o interpretację sztuki przez sztukę. Przymierzanie recytacji do wykonywanego tekstu, refleksja na temat jej interpretacyjnych możliwości i ograniczeń, porównywanie jej z interpretacją krytyczno-badawczą to zasadnicze problemy, które się tu nasuwają.

Recytacja jest sztuką wykonawczą, darstellende Kunst i wśród tych sztuk należałoby szukać jej pokrewieństwa. Tam - obok tancerza, pianisty i skrzypka, obok rzeszy innych artystów wykonawców - znajduje się miejsce recytatora. Wszystkich łączy funkcja wykonywania oraz interpretowania. Łączy ich także podobieństwo tworzywa, jakim się posługują. Jest to tworzywo sensoryczne i jako takie oddziaływa na zmysły odbiorcy. Oddziaływa w różny sposób, np. swoją dynamicznością. Wymieniona cecha, dodajmy, znamionuje tworzywo wszystkich sztuk wykonawczych, jest ich wspólnym mianownikiem i jako taka pozwala zestawiać z sobą sztuki tak odległe, jak recytacja i taniec. Na obszarze występujących tu analogii umieścimy takie zjawiska, jak: rytm, tempo, dynamika oraz inne, oparte na 
substracie dynamiczności współczynniki. Można zatem mówić o recytacji językiem choreografii i na odwrót, oczywiście w ograniczonym zakresie, na wspólnym obszarze zjawisk.

Jeżeli do cechy dynamiczności dodamy materialny, akustyczny substrat głosu, postawimy recytatora w jednym rzędzie ze wspomnianymi pianistą i skrzypkiem. Tutaj podobieństwo zaznacza się w swojej pełnej naoczności. Wystarczy posłuchać komentarza do występu solisty - muzyka, wysłuchać oceny jego gry, w której mowa o zaplanowaniu całości utworu, wyrazistości dźwięku, „głębokich naciśnięciach klawiszy”, tempie, dynamice - stosownej i niestosownej - o czystości uderzenia, zrozumieniu intencji utworu, intencji kompozytora, o poszukiwaniu głębi, żeby się o tym przekonać1. To wszystko zachęca do porównawczych analiz - a zachęca tym bardziej, gdy dodamy do tego sztukę wokalną. Jeden i ten sam instrument, podobne lub identyczne problemy wykonawcze, zwłaszcza w zakresie emisji głosu, czynią te dwie sztuki szczególnie sobie bliskimi.

$\mathrm{Na}$ gruncie wokalnym spotyka się recytator ze śpiewakiem w funkcji interpretacyjnej, a wspólność tę zapewnia fakt, że jeden i drugi wchodzi w kontakt z tekstem i że bywa to tekst jeden i ten sam. Można przecież recytować Trzech budrysów czy Znaszli ten kraj Adama Mickiewicza i śpiewać odpowiednie pieśni Stanisława Moniuszki, można recytować wiersz Tetmajera Pamiętam ciche, jasne, złote dnie lub śpiewać odpowiednią pieśń Mieczysława Karłowicza. Sytuacja zasługuje na to, żeby się nad nią zatrzymać i poświęcić jej kilka chwil refleksji. Przedtem jednak należy się tu uwaga natury metodologicznej, i to uwaga dla naszych rozważań istotna.

Otóż wspólnota tekstu, która cechuje recytację i śpiew, budzi jednak pewne zastrzeżenia. Śpiewak, owszem, podobnie jak recytator prezentuje tekst, ale w przeciwieństwie do recytatora tego tekstu w zasadzie nie interpretuje. Interesuje go inny przedmiot, a mianowicie tekst umuzyczniony. Śpiewak otrzymuje dyrektywę interpretacyjną od kompozytora. Dyrektywa ta ma postać gotowego ukształtowania, różnego rodzaju dezyderatów melodycznych, rytmicznych czy dynamicznych. Wykonując określony utwór wokalny, realizując całokształt jego dyrektyw, odnosząc się do niego, śpiewak ustosunkowuje się, owszem, również do tekstu i współtworzy jego interpretację, ale jest to interpretacja pośrednia. W bezpośredniej, interpretacyjnej relacji do tekstu stoi natomiast kompozytor, i to jemu należy się miejsce obok recytatora.

Za dość powszechne zjawisko należy uznać to, że kompozytor bywa zarazem wykonawcą utworu, a nierzadko autorem słów. Dzieje muzyki dostarczają wielu przykładów łączenia tych funkcji, zwłaszcza gdy chodzi o muzykę instrumentalną, a można tu wymienić dwóch genialnych kompozytorów i wirtuozów fortepianu zarazem: Fryderyka Chopina i Franciszka Liszta ${ }^{2}$. Ale to nie zmienia istoty rzeczy. Każdy z nich jako wykonawca realizował swoje kompozytorskie dyrektywy. Warto dodać, że przykładem oddalonym w czasie, ale

\footnotetext{
1 Powyższy fragment wyrósł z ducha komentarzy do gry uczestników ostatniego Konkursu Chopinowskiego relacjonowanego w II programie Polskiego Radia.

2 Należy tu również przywołać postaci poetów śpiewających swoje wiersze ze swoim własnym opracowaniem muzyczno-wokalnym, np. Marcina Świetlickiego czy poetę-„,barda” Edwarda Stachurę. Notabene dzisiejsza poezja śpiewana dostarcza wielu interesujących przykładów różnorodnych relacji, jakie tu mogą zachodzić. Zmiany dokonywane przez kompozytora w tekście, jak w kompozycji Zygmunta Koniecznego do wiersza Tuwima Przy okragłym stole, różne kompozytorskie interpretacje jednego wiersza, czego przykładem Upojenie Stanisława Grochowiaka, opracowywane muzycznie przez Stanisława Syrewicza, Annę Marię Jopek i Adama Andryszczyka, wykonywane odpowiednio przez: Daniela Olbrychskiego, Annę Marię Jopek w duecie z Michałem Żebrowskim oraz Adama Andryszczyka - oto przykłady takich relacji.
} 
bliższym może tematycznie byłaby sytuacja artystyczna średniowiecznego trubadura, również twórcy i zarazem wykonawcy. Tak czy inaczej, to kompozytor jest interpretatorem tekstu i patrząc z tego punktu widzenia, to on sytuuje się na tej samej co recytator płaszczyźnie.

Warto zatrzymać się przy tej relacji i przyjrzeć się jej postaciom, ściślej mówiąc, skali występujących tu podobieństw. Należy bowiem stwierdzić, że przy podkreślanej jednolitości tworzywa oraz interpretowanego przedmiotu, czyli tekstu, interesująca nas relacja przedstawia dość pojemne spektrum większego czy mniejszego przybliżenia. Może być tak, że recytacja i utwór wokalny wykazują duże podobieństwo, może też być tak, że drogi ich rozchodzą się wyraźnie i zdecydowanie. Decydują o tym w zasadzie dwie strony relacji, recytacyjna i wokalna. Bywa, że recytacja przypomina w pewien sposób formę pieśni czy jakiegoś ariosa, eksponując element wokalny wtedy, gdy realizuje dokładnie dyrektywę formalną ${ }^{3}$ - zwłaszcza wersologiczną - wtedy, gdy wyodrębnia wyraziście dominujące w tekście figury retoryczne: okres i różnego rodzaju gradacje, gdy każe temu wszystkiemu dominować w swojej prezentacji. W ten sposób można sobie wyobrazić recytację poniższego fragmentu:

Boże! kto Ciebie nie czuł w Ukrainy Błękitnych polach, gdzie tak smutno duszy, Kiedy przeleci przez wszystkie równiny Z hymnem wiatrzanym, gdy skrzydłami ruszy Proch zakrwawionej przez Tatarów gliny, $\mathrm{W}$ popiołach złote słońce zawieruszy, Zamgli, sczerwieni i w niebie zatrzyma Jak czarną tarczę z krwawymi oczyma;

Kto Cię nie widział nigdy, wielki Boże! Na wielkim stepie, przy słońcu nieżywym, Gdy wszystkich krzyżów mogilne podnoże Wydaje się krwią i płomieniem krzywym, A gdzieś daleko grzmi burzanów morze, Mogiły głosem wołają straszliwym, Szarańcza tęcze kirowe rozwinie, Girlanda mogił gdzieś plynie i ginie;

Kto Ciebie nie czuł w natury przestrachu, Na wielkim stepie albo na Golgocie, Ani śród kolumn, które zamiast dachu Mają nad sobą miesiąc i gwiazd krocie, Ani też w uczuć młodości zapachu Uczul, że jesteś, ani rwąc stokrocie, Znalazł w stokrociach i niezapominkach, A szuka w modłach i w dobrych uczynkach, Znajdzie - ja sądzę, że znajdzie $[\ldots]^{4}$

\footnotetext{
3 O dyrektywie formalnej w powiązaniu z dyrektywą wyrazową będzie jeszcze mowa.

4 J. Słowacki, Beniowski, [w:] idem, Utwory wybrane, t. 1, Warszawa 1964, s. 354-355.
} 
Kontynuując nasze rozważania, zaznaczmy, że więcej do powiedzenia ma tutaj druga strona relacji, reprezentowana przez kompozytora. Recytator bowiem, jakkolwiek by nie podchodził do swego wykonawczego zadania, nie może się od tekstu oddalić. Jego światem jest świat dyrektyw wykonywanego utworu, i do nich powinien się stosować. W przeciwnym wypadku nie będzie tym, kim jest z powołania. Inaczej - kompozytor. Ten ma większe możliwości uniezależnienia się od dyrektywy tekstu, ba, może się z nią rozminąć, nie tracąc swojej kompozytorskiej tożsamości. Innymi słowy może on stać w pobliżu recytatora, może go w ogóle nie dostrzegać. W związku z tym, co wyżej powiedziano, należy zatrzymać się przez chwilę przy relacji: kompozycja wokalna - tekst ${ }^{5}$.

Problem ten ma swoje długie dzieje, których nie sposób tu przedstawiać. Powiemy natomiast, że jego świadomość uwypukliła się zwłaszcza w czasach Cameraty florenckiej i związanego z nią rozwoju monodii akompaniowanej. Dał jej wyraz m.in. Giulio Caccini $\mathrm{w}$ przedmowie do swojego zbioru arii i madrygałów Le nuove musiche ${ }^{6}$ (Florencja 1601). Chodziło o „koncepcję nadrzędnej roli poetyckiego słowa w stosunku do muzyki: śpiewna deklamacja poezji (parlar cantando) zamiast śpiewu podpierającego się poezją (cantar parlando) narzucającego jej reguły i struktury muzyki" ". Ten podział, ta opozycja, pomijając okolicznościowe tendencje - „śpiewna deklamacja” - oddaje istotę rzeczy, gdy chodzi o słowo i jego szatę muzyczną. W jego kręgu sytuują się różne modyfikujące relację zagadnienia. Wymienimy tu najpierw formalną i wyrazową realizację dyrektyw tekstu. „W pierwszym przypadku kompozytor kieruje się głównie właściwościami konstrukcyjnymi tekstu i stara się je uwydatnić przy pomocy środków muzycznych. W drugim przypadku o właściwościach utworu muzycznego decydują wyłącznie walory wyrazowe jego treści, tzn. tekstu"s.

Powyższy podział należy uznać za dogodny sposób charakterystyki, a zwłaszcza kategoryzacji przy omawianiu zagadnienia wokalnych i, co dla nas szczególnie istotne, recytatorskich ukształtowań tekstu. Do podziału tego jeszcze nawiążemy. „Podkładanie tekstu pod muzykę” oraz „umuzycznienie istniejącego już tekstu” to kolejny sposób widzenia, problemu. Wspomina o nim Elżbieta Sierosławska ${ }^{9}$, która wychodzi z założenia, że w jednym i drugim wypadku należy „uwzględnić związki słowa z muzyką”10. Oznaczałoby to, że kolejność podejmowanych tu czynności twórczych nie ma, a przynajmniej nie musi mieć, wpływu na ich ostateczny wynik. Warto również dodać, iż na zagadnienie interesujących nas relacji można spojrzeć nie tylko od strony zasad, jak to wyżej czyniliśmy, lecz również od strony sposobów. Cytowana tu autorka, Elżbieta Sierosławska pisze:

\footnotetext{
${ }^{5}$ Odnośne tu propozycje pochodzą głównie ze świata muzyki.

6 Giulio Caccini, wybitny kompozytor i śpiewak przełomu XVI i XVII wieku, współtwórca gatunku operowego.

7 Zob. J. Ekiert, Bliżej muzyki. Encyklopedia, Warszawa 2006, s. 477. Parlar cantando - mówić śpiewając, cantar parlando - śpiewać mówiąc.

8 J. Chomiński, K. Wilkowska-Chomińska, Pieśń [w serii tychże autorów: Formy muzyczne], Polskie Wydawnictwo Muzyczne 1974, s. 27-28.

9 Zob. E. Sierosławska, Fraza muzyczna a fraza tekstowa. Prozodia w przekładzie arii operowych, Kraków 2008, s. 21.

10 Ibidem.
} 
Ogólnie rzecz biorąc można rozróżnić następujące typy umuzycznienia tekstów:

1) melodyka deklamacyjna uwzględniająca elementy prozodyczne tekstu (np. w sposobie rapsodycznej recytacji dramatów i eposów antycznych oraz podczas czytania tekstów liturgicznych),

2) muzyczno-autonomiczna melodyka sylabiczna (np. w pieśni),

3) melodyka melizmatyczna w sztucznie skomponowanej muzyce wokalnej ${ }^{11}$.

Podział: muzyka dla teksu (parlar cantando), tekst dla muzyki (cantar parlando) można odnieść do całego obszaru sztuki wokalnej, zarówno form wielkich, z operą przede wszystkim, jak i form małych, reprezentowanych głównie przez różne odmiany pieśni. Dzieje opery znają sytuacje, gdy kunsztowne, koloraturowe belcanto włoskiego zwłaszcza baroku usuwało w cień słowo i dramaturgię i na odwrót, gdy słowo stanowiło ważne współtworzywo z niekorzyścią dla melodycznie zorientowanej arii, a zarazem z korzyścią dla recytatywu. Na razie skupimy naszą uwagę na pieśni, uwzględniając jej egzemplifikacyjną dogodność. Pieśń jest dobrym pendant do wykonań recytacyjnych ${ }^{12}$, ze względu na charakter tekstu, m.in. co do rozmiarów, i ze względu na podnoszoną tu dogodną możliwość postrzegania jednego i tego samego tekstu w obu - wokalnej i recytacyjnej - sytuacjach.

Interesuje nas, rzecz jasna, pieśń, która spełnia postulat mówienia przez śpiew (parlar cantando), bo tylko ona pozwala na porównawcze rozważania. Pieśń taka rozkwitła zwłaszcza, podobnie jak sam gatunek ${ }^{13}$, w okresie romantyzmu i przeciągnęła swoją obecność na dalsze lata. Istnieje tu wiele przykładów na to, że „słowo i nuta tryskają pospołu z jednej wyobraźni” ${ }^{14}$, można odnaleźć wiele pieśni nacechowanych kongenialnością słowa i muzyki, ponieważ za jednym i drugim stoi genialny albo wybitny wśród wybitnych twórca. Przykładów takich dostarcza również twórczość polska, żeby wymienić jednym tchem: Moniuszko - Mickiewicz, Chopin - Mickiewicz i Krasiński, Karłowicz - Słowacki i Tetmajer. Pieśniarska twórczość europejska dostarcza również takich przykładów, owa równowaga dwóch stron nie zawsze występowała. Czasem pieśń nie dorównywała słowu, czasem pieśń górowała nad słowem swoim artystycznym walorem, dokonując jego nobilitacji i włączając w nurt wielkiej światowej sztuki, jak to dzieje się z pewnością w wypadku Schuberta czy Chopina. Oba wypadki są znamienne, ponieważ można je odnieść do sytuacji recytatorskich, uprzytomnić przez analogie znaczenie recytacji w jej roli artystycznej promocji tekstu albo jego deprecjacji. Wskazuje zarazem na możliwości muzyki, gdy chodzi o nobilitację tekstu czy jego uszlachetnienie.

Znaczenie tekstu, a ściślej - jego wpływ na kompozycję wokalną we wspominanej wyżej twórczości pieśniarskiej, był powszechny Łatwo go dostrzec w pieśni o formie przekomponowanej, ale łatwo też wysłuchać go w zwyczajnej pieśni zwrotkowej z ewentualnym elementem wariacyjnym. O wyrazowości pieśni decyduje tu nastrój, jaki ta stwarza, przewodni motyw uczuciowy dyktowany przez całokształt tekstu. Do takich pieśni zaliczymy m.in. trzy znane utwory Stanisława Moniuszki: szybką jak ruch wrzeciona Przaśniczkę,

11 Zob. ibidem, s. 30. Autorka w przypisie cytuje: W. Gruhn, Musiksprache - Sprachmusik - Textvertonung. Aspekte des Verhältnissen von Musik, Sprache und Text, Frankfurt am Main-Berlin-München 1978, s. 22-23.

12 O pokrewnym zagadnieniu: pieśń - słowo, zob. m.in.: M. Bristiger, Zwiqzki muzyki ze słowem. Z zagadnień analizy muzycznej, Warszawa 1986; M. Tomaszewski, Muzyka w dialogu ze słowem, Kraków 2003.

13 Mówimy o rozkwicie pieśni, a nie o jej początku.

14 Zob. P. Kamiński, Tysiac i jedna opera, t. 2, Warszawa 2008, s. 652. Autor, Piotr Kamiński, pisze te słowa w związku z Tannhäuserem Ryszarda Wagnera. 
poważną, szeroko melodycznie zaplanowaną dumkę Kozak oraz wielkiej piękności pieśń Znaszli ten kraj. Ta ostatnia, napisana do wiersza Mickiewicza, spełnia właśnie owe cechy kongenialności, o których pisaliśmy wyżej. Pieśni te, choć odbiegają swoim ukształtowaniem i charakterem od wzoru recytatorskiego, mogą spełnić wobec recytatora rolę pożądanej inspiracji, rzucić trochę interesującego światła na zjawiska rytmiczno-frazeologiczne i przypomnieć o roli pierwiastka dynamicznego, zwłaszcza różnie wykonywanych gradacji. Przede wszystkim zaś unaocznić zjawisko korespondencji treści i formy w kontekście określonych nastrojów.

W kręgu omawianych pieśni spotykamy wiele takich, które przybierają tzw. formę przekomponowaną. Wspominałem już o nich, teraz pora wyjaśnić, że chodzi o typ pieśni, w których „każda zwrotka opracowywana jest w odmienny sposób” ${ }^{15}$, tak pod względem melodycznym, jak innych struktur. Oczywiście zmiany te są dyktowane przez formalny i wyrazowy kształt poszczególnych zwrotek. Są to zatem zmiany natury interpretacyjnej. Dodajmy, że autor monografii o pieśni, Józef Chomiński, uznaje expressis verbis formę przekomponowaną za najprostszy przykład zależności wyrazowej i wiąże z nią daleko idące modyfikacje. Oto co pisze w związku z tym:

Jako najprostszy przykład zależności wyrazowej przytoczyć można tzw. pieśń przekomponowaną. Jej struktura muzyczna nie respektuje ani zwrotkowej zasady architektonicznej, ani rozmiarowych prawidłowości w budowie wersów. Przeciwnie, właśnie względy wyrazowe wymagają rozbudowy fraz i podkreślenia akcentów, wbrew symetrycznemu układowi wersów. Oczywiście, przykłady te obrazują problematykę zależności tekstu i muzyki w dużym skrócie i uproszczeniu ${ }^{16}$.

Podobnie jak w przypadku pieśni zwrotkowej, również w tym wypadku, pieśni przekomponowanej, możemy udać się po przykłady do twórczości polskiej. Tworzyli takie pieśni: Moniuszko, Karłowicz i Szymanowski, żeby wymienić tych najwybitniejszych. Przywołajmy tu dwa tytuły pieśni Karłowicza: Skąd pierwsze gwiazdy do fragmentu poematu $W$ Szwajcarii Słowackiego i pieśń Śpi w blaskach nocy ${ }^{17}$ do wiersza Heinricha Heinego. Gdybyśmy zechcieli przymierzyć pieśn przekomponowaną do wyobrażonej lub realnej postaci głosowej recytacji, to dostrzeglibyśmy więcej podobieństw, tkwiących w samej zmienności interpretacyjnej, wynikającej z dążenia do większej szczegółowości ekspresji czy narracji, które składają się na szczegółowość interpretacyjną. Pieśń przekomponowana zaprasza niejako do recytacji. Nie może zresztą nie być odczuwana jako recytacji krewna już przez sam fakt, że wymyka się schematyzmowi powtarzalności występującemu w pieśni zwrotkowej.

Pożądanym uzupełnieniem powyższych rozważań będzie odwołanie się do geniusza pieśni romantycznej, Franza Schuberta, ściślej jego Króla olch (Erlkönig), pieśni skomponowanej do wiersza Johanna Wolfganga Goethego, której nie trzeba przedstawiać, zważywszy jej powszechną znajomość. Król olch z pewnością należy do tych pieśni, w których - jak

\footnotetext{
15 Encyklopedia muzyki, red. A. Chodkowski, Warszawa 1995, s. 727.

16 J. Chomiński, K. Wilkowska-Chomińska, op. cit., s. 28.„Formalny i „wyrazowy”: zob. przypis 8 wraz z odpowiadającym mu cytatem.

17 Wymienione pieśni nie wyczerpują oczywiście listy pieśni o formie przekomponowanej lub - dodajmy -wariacyjnej Karłowicza.
} 
już pisaliśmy wcześniej - „słowo i nuta tryskają pospołu z jednej wyobraźni” i w których jedno i drugie jest wielkiego lotu. Rysująca się tu genialnie zbieżność między tekstem a muzyką zachodzi zarówno na płaszczyźnie wyrazowej, jak i formalnej. Pierwsza wyrasta na całej, odpowiedniej do treści dramatycznej nastrojowości, druga na zgodności z dyrektywami z zakresu poetyki. Wiersz, który posłużył jako słowa do pieśni, jest balladą, postawił więc kompozytora przed zadaniami związanymi z jego liryczno-epickim charakterem oraz pierwiastkami dramatycznymi, tu w tym konkretnym utworze szczególnie widocznymi. Dramatyczna i tragiczna w finale narracja, dialog ojca z synem, kuszenie i groźba króla olch - to wszystko razem genialnie uwzględnił młody Schubert. Pieśń wykazuje dużą zbieżność z wyobrażoną recytacją, sprawia wrażenie, że powstała wręcz na substracie deklamatoryjnym, „poprawionym” jedynie o pierwiastek muzyczności ${ }^{18}$.

A oto jej fragment:
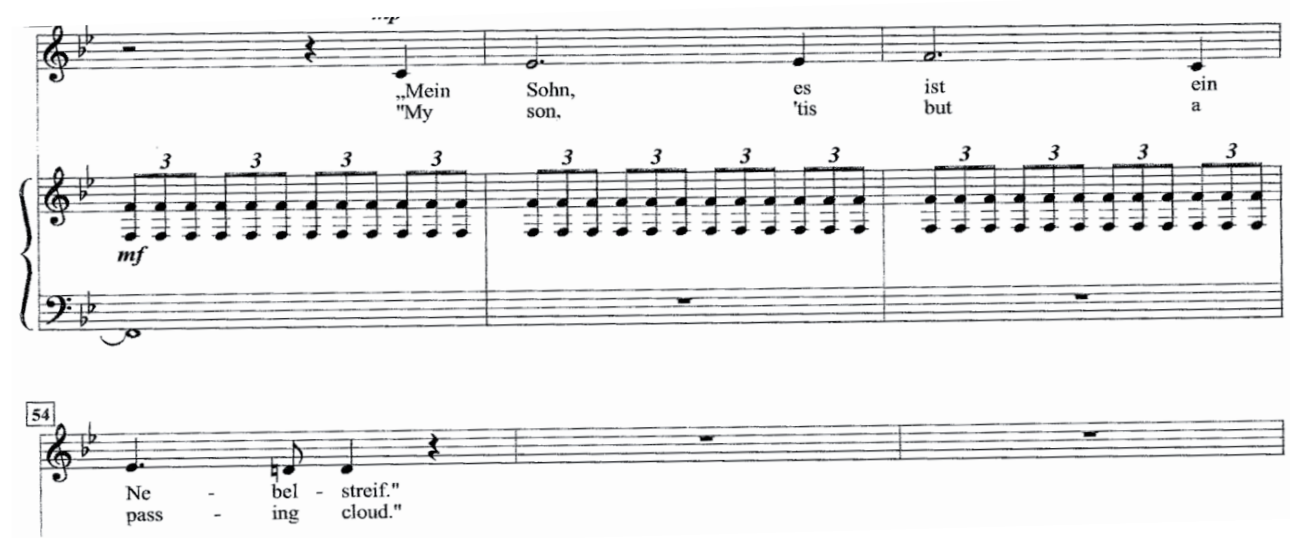

Dramatyczne, uspokajające zarazem słowa ojca są wypowiadane w metrum jambicznym, które kompozytor uwypukla poprzez odpowiedni rozkład tekstu na takty. Metrum to pełni bowiem ważną rolę jako jeden ze środków ekspresji.

Przy Schubercie powinniśmy jeszcze pozostać choćby ze względu na jego dzieło Sobowtór ${ }^{19}$, służące za przykład pieśni deklamacyjnej, która należy do odmian pieśni przekomponowanej. Pora jednak przenieść się na chwilę do czasów Maurice’a Ravela, Claude’a Debussy'ego i Karola Szymanowskiego, bo to właśnie pod ich kompozytorskim piórem rozkwitała deklamacyjność melodii. W tych czasach tworzył również Arnold Schönberg, zwracający naszą uwagę jako autor cyklu Pierrot lunaire, „wykonywanego techniką «Sprechgesang » polegającą na recytowaniu - a nie śpiewaniu - podanych wysokości dźwięków”20. Przedstawiamy niżej jego krótki, ograniczony do pięciolinii dla głosu fragment pieśni zatytułowanej Eine blasse Wäscherin (Pewna blada praczka). Prezentujemy go, zwracając uwagę na charakterystyczną linię melodii oraz znaki artykulacyjne.

18 Z konieczności pomijamy zagadnienie akompaniamentu muzycznego i jego (nie do przecenienia) wpływu na budowanie nastroju utworu. Notabene akompaniament ten posiada cechy samoistnego dzieła sztuki.

19 F. Schubert, Der Doppelgänger, w zbiorze Schwannengesang do wiersza H. Heinego.

20 Internet: pl.wikipedia.org/Wiki/Melodramat. 


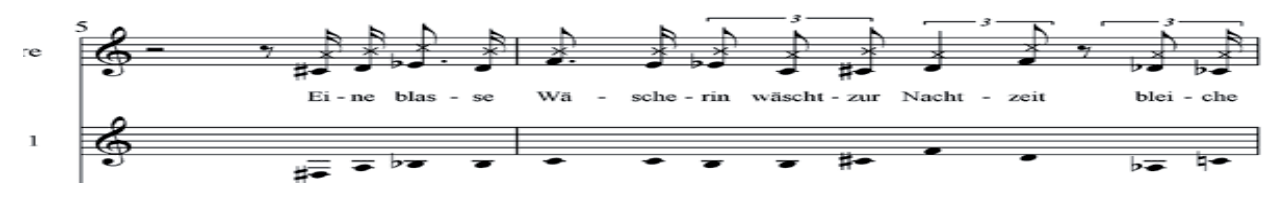

Przechodząc do bliższych nam czasów, wspomnimy o autorze Trzech poematów Henriego Michaux, Witoldzie Lutosławskim. Raz - z racji ich egzemplifikacyjności dla omawianego problemu, dwa - ze względu na deklaracje kompozytora w jego wypowiedziach na temat własnego warsztatu twórczego i roli, jaką w nim pełni intonacja języka mówionego.

Zauważyliśmy wyżej, że interesująca nas problematyka rozciąga się na cały obszar wokalny, a zatem również na wielkie formy: operę, oratorium i kantatę. Do nich też, ściślej do opery, nawiążemy w naszych dalszych rozważaniach. Nawiążemy przez jedną z dwóch zasadniczych form operowej wypowiedzi, a mianowicie przez recytatyw, zwłaszcza jego odmianę - recitativo secco - ograniczoną do ubogiego, w zasadzie klawesynowego akompaniamentu. Recytatyw bywa niekiedy łudząco podobny do zwykłego mówienia, co w jego roli posuwania akcji jest w pełni zrozumiałe. Przytoczmy w związku z tym odpowiednie tu zdanie dyrygenta niemieckiego z pierwszej połowy XX wieku, Brunona Waltera:

W przeciwieństwie do tych rzadkich, kulminacyjnych momentów, w których muzyka przestaje służyć dramatowi, by nad nim zapanować, istnieją też chwile, w których przyjmuje ona rolę pomocniczą, w większym lub mniejszym stopniu poddaną akcji czy tekstowi. Nazywa się to recitativo secco, który wyznacza muzyce skromną rolę: tu jedyną różnicą między operą a dramatem mówionym jest to, że kompozytor zaznaczył wysokość dźwięku i charakter rozmowy aktorów ${ }^{21}$.

Bruno Walter mówi o „jedynej różnicy”, sugerując słusznie wzajemną bliskość recytatywu i recytacji, potwierdzając nasze dotychczasowe uwagi o wzajemnych, niekiedy bardzo ścisłych pokrewieństwach sztuki recytatorskiej i wokalnej. Ale „jedyna” czy nie „jedyna”, różnica istnieje, a polega ona na tym, że - przypomnijmy - „kompozytor zaznaczył wysokość dźwięku i charakter rozmowy aktorów”. I o tę zaznaczoną wysokość dźwięku chodzi. Recytacja takich instrukcji nie ma i mieć nie może. Granica, jaka zaznacza się między omawianymi dwiema interpretacjami, choćby najwęższa, jest granicą nie do przekroczenia, ponieważ ma charakter jakościowy. To nie jest sprawa więcej czy mniej śpiewania lub mówienia, to sprawa innej przynależności. Instrukcję dla kompozytora stanowi określona dyrektywa muzyczna, płynąca z tradycyjnych skal czy z nowych rozwiązań warsztatowych, instrukcja dla recytatora zostaje zapisana na „skali”, jaką oferuje recytowany tekst.

A jaką „skalę” oferuje tekst? W jaki sposób tekst może stanowić dyrektywę dla głosowego tworzywa recytacji? Nietrudno tu o odpowiedź: dyrektywą jest całokształt akustyczny, jaki wyłania się z semiozy tekstu i jego formalnego ukształtowania, co w przełożeniu na znany już nam podział oznacza dyrektywę wyrazową i formalną. Recytator staje przed tą całością, złożoną z najszerzej pojętej prozodii, ze składni, fonetyki, semantyki i czyni ją przedmiotem swojej interpretacji. Dokonuje wyboru z bogatej i różnorodnej oferty tekstu w procesie konkretyzacji czytelniczo-wykonawczej, buduje z niej określony akustycz-

${ }^{21}$ B. Walter, O muzyce i muzykowaniu. Za: J. Ekiert, op. cit., s. 423. 
ny model i łączy ze znanymi sobie sposobami ich głosowej materializacji. Można by nawet powiedzieć, że recytator wykonuje swoim głosem partyturę zapisaną w tym samym głosowym tworzywie. Oznaczałoby to modyfikację naszej dotychczasowej analogii. Zamiast relacji: (śpiew - głos : pieśń - głos) : (recytacja - głos : tekst - język) otrzymalibyśmy relację: (śpiew - głos : pieśń - głos) : (recytacja - głos : kształt akustyczny wyłoniony z tekstu - głos). Tym samym recytator stanąłby w jednym rzędzie ze śpiewakiem, a sięgając dalej, z wymienianym tu na zasadzie pars pro toto pianistą. Różni go jednak od nich inny zapis partytury. Obaj wymienieni, śpiewak i pianista, korzystają z partytury zapisanej w takim tworzywie, jakim sami się posługują, natomiast partytura recytatora jest zapisana w tekście, jest w nim zanurzona i tworzy z nim spójną, organiczną całość. Trzeba też koniecznie dodać, że ta partytura cechuje się daleko zakrojoną wariantywnością, stawia recytatora przed bogatym wyborem możliwości interpretacyjnych, co sprawia, że czyni ona recytację sztuką o dużym pierwiastku aleatoryczności, gdyby porównać ją z określonym rodzajem twórczości muzycznej.

Powróćmy jeszcze do sprawy recytatywu i przytoczmy inne, dotyczące go zdanie, tym razem Johanna Mathesona: „Aby dobrze skomponować jeden recytatyw - biorąc pod uwagę uczucia i krój zdania - trzeba większej umiejętności i zręczności niż do skomponowania dziesięciu arii na zwykłą modłę"22. Matheson pisał te słowa w XVII wieku, kiedy aria goniła arię, koloratura - koloraturę. Nie umniejsza to jednak wagi jego wypowiedzi.

Ukłon w stronę recytatywu, jaki wykonał Matheson, okazuje się dla nas o tyle istotny i wręcz pochlebny, że jest to zarazem ukłon w stronę recytacji, a to ze względu na owe „uczucia”, a zwłaszcza „krój zdania”. Również recytację można uznać za trudniejszą niż niejedno opracowanie wokalne, postrzegając ją z pozycji koncepcji wykonawczej i z pozycji samego wykonania. Mało kto o tym wie, mało kto wie również o tym, że recytacja może być wielką, porywającą sztuką. Jest to ważne dla nas stwierdzenie dzisiaj, w dobie mniejszych szans dla słowa recytowanego, które przegrywa społecznie z innymi formami kolportażu ${ }^{23}$, a którego wartości nie można przecenić.

\section{Bibliografia}

Bristiger Michał, Związki muzyki ze stowem. Z zagadnień analizy muzycznej, Warszawa: Polskie Wydawnictwo Muzyczne, 1986.

Chomiński Józef, Wilkowska-Chomińska Krystyna, Pieśń, [w:] idem, Formy muzyczne, t. 3, Kraków: Polskie Wydawnictwo Muzyczne, 1974.

Ekiert Janusz, Bliżej muzyki. Encyklopedia, Warszawa: Muza, 2006.

\footnotetext{
22 J. Matheson, Componimenti musicali, 1706. Za: J. Ekiert, op. cit., s. 423.

${ }^{23}$ Mam tu na myśli kolportaż medialny, oferujący wokalne formy tekstu. Samo zjawisko jest oczywiście pożyteczne i warte poparcia. Chodzi jednak o to, że wśród tej pieśniowości recytacja wydaje się ubogą krewną. Poza tym pieśniowość czy będzie na wysokim poziomie, czy będzie po prostu licha jako interpretacja, jakoś obroni się w swojej masie głosowej, natomiast recytacja musi być bezwzględnie bardzo dobra. Inna sprawa, że wśród wybitnych utworów muzyczno-wokalnych znajduje niekiedy swoje miejsce słowo mówione. Za przykład niech posłuży Ocalały z Warszawy Arnolda Schönberga czy Brygada do zadań specjalnych oraz Siedem bram Jerozolimy Krzysztofa Pendereckiego.
} 
Encyklopedia muzyki, red. Andrzej Chodkowski, Warszawa: Wydawnictwo Naukowe PWN, 1995. Gruhn Wilfried, Musiksprache - Sprachmusik - Textvertonung. Aspekte des Vehältnissen von Musik, Sprache und Text, Frankfurt am Main-Berlin-München: Diesterweg, 1978.

Gwizdalanka Danuta, Historia muzyki. Podręcznik dla szkót muzycznych. Cz.1, Kraków: Polskie Wydawnictwo Muzyczne, 2005.

Kamiński Piotr, Tysiąc i jedna opera, t. 2, Warszawa: Polskie Wydawnictwo Muzyczne, 2008.

Sierosławska Elżbieta, Fraza muzyczna a fraza tekstowa. Prozodia w przekładzie arii operowych, Kraków: Wydawnictwo Naukowe Akademii Pedagogicznej, 2008.

Słowacki Juliusz, Beniowski, [w:] idem, Utwory wybrane, t. 1, Warszawa: Państwowy Instytut Wydawniczy, 1964.

Tomaszewski Mieczysław, Muzyka w dialogu ze słowem, Kraków: Akademia Muzyczna, 2003. 